研

究

固体酸化物イオン導電体 / 金電極系での化学ポテンシャルシフトを用いた CO センシング機構

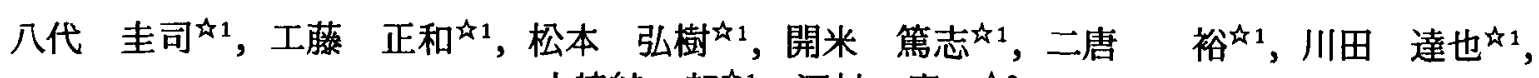 \\ 水崎純一郎圤 1 , 河村 畫一2 \\ 41 東北大学科学計湘研究所, ₹ 980-8577 仙台市青葉区片平 2-1-1. \\ 22 東京工業大学大学院材料工学尃攻, $=152-8552$ 目黒区大岡山 2-12-1.
}

\title{
CO Sensing Mechanism with Chemical Potential Shifting on Au/YSZ Interface
}

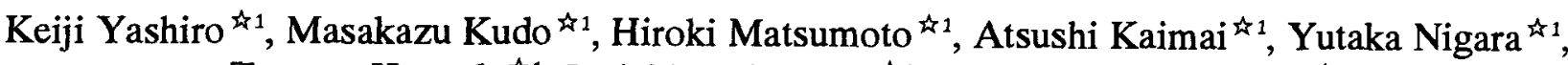 \\ Tatsuya Kawada ${ }^{\text {t } 1}$, Junichiro Mizusaki ${ }^{\text {th } 1}$ and Kenichi Kawamura ${ }^{\text {th } 2}$

\footnotetext{
${ }^{\not 1}$ Research Institute for Scientific Measurements, Tohoku University, 2-1-1 Katahira, Aoba-ku, Sendai 980-8577.

2 2 Department of Metallurgical Engineering, Tokyo Institute of Technology, 2-12-1 O-okayama, Meguro-ku, Tokyo $152-8552$.
}

Received June 12, 2000

\section{SYNOPSIS}

The electrochemical property of the galvanic cell, $P\left(\mathrm{O}_{2}\right)^{\mathrm{I}}+P(\mathrm{CO}), \mathrm{Au} / \mathrm{YSZ} / \mathrm{Pt}, P\left(\mathrm{O}_{2}\right)^{\mathrm{I}}$, has been studied for the applications of $\mathrm{CO}$ sensor. In order to elucidate the $\mathrm{CO}$-sensing mechanism on Au/YSZ interface, steady state polarization measurements were carried out at $873-1073 \mathrm{~K}$ in $\mathrm{O}_{2}-\mathrm{Ar}, \mathrm{CO}-\mathrm{CO}_{2}, \mathrm{CO}_{-} \mathrm{O}_{2}-\mathrm{Ar}$ systems. The quantitative analysis of the $\mathrm{I}-\mathrm{V}$ characteristics revealed the kinetics of the electrode reaction with $\mathrm{O}_{2}, \mathrm{CO}$ and $\mathrm{CO}_{2}$. The current density at $\mathrm{Au} / \mathrm{YSZ}$ interface in $\mathrm{CO}-\mathrm{O}_{2}-\mathrm{Ar}$ system can be formulated. As a result, it was confirmed that mixed potential was generated by a small amount of $\mathrm{CO}$ in oxygen-containing streams.

KEYWORDS

CO sensor, mixed potential, electrode kinetics, solid electrolyte

\section{1 緒 言}

特定の化学物質の物理量もしくは化学量を捉えて, 電気信 号に変換するテバイスを化学センサーと呼ぶ. 現在, 環境・人 体への悪影響が心配される規制物質等の濃度モニタリング用 として安価な化学センサーへの需要が高まっている.有毒ガ スであるCO用のガスセンサーとしては $\mathrm{SnO}_{2}$ などを用いた半 導体ガスセンサーが既に実用化されている1).しかし, 感度か 数百 ppmオーダーと高くないため, 高感度で連続的に作動す るセンサーの開発が待たれている. Okamotoらは白金を電極 にしたジルコニアセンサー $(\mathrm{Pt} / \mathrm{YSZ} / \mathrm{Pt})$ が空気中あるいは希薄 酸素中の微量の COによって起電力加 Nernst 電位によって決 まる值から若干還元側にずれる現象(混成電位)を利用した高 感度な固体電解質型 $\mathrm{CO}$ センサーを提示している27.この混成 電位式の固体電解質センサ一の特徵として,感度が高いこと, および電極の速度論パラメータによりセンシング性能が決ま るため, 電極の材質, 形状など多くのパラメー夕により性能 の制御が可能であることが挙げられる. 報告されている湿成 電位型COセンサーの例としては他に $\mathrm{LaMnO}_{3} / \mathrm{YSZ} / \mathrm{LaMnO}_{3}{ }^{3}$, $\mathrm{CdO} / \mathrm{YSZ} / \mathrm{SnO}_{2}{ }^{4}, \mathrm{Pt}^{2} / \mathrm{Ce}_{0.8} \mathrm{Gd}_{0.2} \mathrm{O}_{2} / \mathrm{Au}^{5}{ }^{5}, \mathrm{Pt} / \mathrm{YSZ} / \mathrm{Pt}$ (電流検知型) などがある.本報では $\mathrm{CO}, \mathrm{O}_{2}$ ガス共存下での混成電位の発生
に着目して, Au/YSZ界面でのCOによる化学ポテンシャルシ フトの発現㙨構を電極反応過程の解析により明らかにするこ とを目的とする。

\section{1 湿成電位}

\section{2 原理}

微量の $\mathrm{CO}$ と $\mathrm{O}_{2}$ が非平衡状態で共存し，ぞれそれのガスの 電気化学反応が気相・電極・電解質の三相界面で独立に起己 ると仮定したとき，予想されるCO- $\mathrm{O}_{2}$ Ar雾囲気中での電流一 電極電位曲線を Fig.1に示す.この系の電流一電極電位曲線は $\mathrm{O}_{2}-\mathrm{Ar}$ 系の電流一電極電位曲線と $\mathrm{CO}-\mathrm{CO}_{2}$ 系の電流一電極電位 曲線の和として表せる.よって, $\mathrm{CO}-\mathrm{O}_{2}-\mathrm{Ar}$ 雾囲気中での平衡 電位(OCV) は微量 $\mathrm{CO}$ の酸化反応，すなわち $\mathrm{CO}_{2} \mathrm{CO}_{2}$ 系のア ノード反応 $\left(\mathrm{CO}+\mathrm{O}^{2-} \rightarrow \mathrm{CO}_{2}+2 \mathrm{e}^{-}\right)$の電流と $\mathrm{O}_{2}-\mathrm{Ar}$ 系の電流が相 殺して0になる電位となる。これを混成電位と呼ぶ.

\section{2 電極電位}

Fig.2に示すような作動極(WE)一参照極(RE)間の電位差は, 直接には両電極間の電子の電気化学ポテンシャル $\eta_{\mathrm{e}}$ の差とし て与えられる.よって RE-WE間の電位差 $E$ は，

$$
E F=\eta_{c}(\mathrm{RE})-\eta_{\mathrm{e}}(\mathrm{WE})
$$


と表される.Fはファラテー定数である.外部に電流を取り出 さないときには, 電極と電解質 (ELY)の間では $\eta_{\mathrm{c}}$ が等しくな るように電子の授受が起こり，

$$
E F=\eta_{\mathrm{e}}(\mathrm{ELY}, \mathrm{RE})-\eta_{\mathrm{e}}(\mathrm{ELY}, \mathrm{WE})
$$

となる.ここで, $\eta_{c}(\mathrm{ELY}, \mathrm{RE}), \eta_{\mathrm{c}}(\mathrm{ELY}, \mathrm{WE})$ はそれそれ ELY/ RE, ELY/WE界面の電解質側の電子の電気化学ポテンシャル である.また，構成要素間では局所的な熱力学平衡が成立す ると考えられるので, 例えば酸化物イオン導電体では $\mu_{0}$ を酸 素の化学ポテンシャルとして,

$$
\eta_{\mathrm{O}^{2-}}=\mu_{\mathrm{o}}+2 \eta_{\mathrm{e}}
$$

という関係が固体内部のいかなる場所でも成立している. よって,

$$
\begin{aligned}
2 E F= & \mu_{\mathrm{o}}(\mathrm{ELY}, \mathrm{WE})-\mu_{\mathrm{o}}(\mathrm{ELY}, \mathrm{RE}) \\
& -\left\{\eta_{\mathrm{O}^{2}}(\mathrm{ELY}, \mathrm{WE})-\eta_{\mathrm{O}^{2-}}(\mathrm{ELY}, \mathrm{RE})\right\}
\end{aligned}
$$

右辺の中括弧内は電解質中でのイオン伝導によるボテンシャ

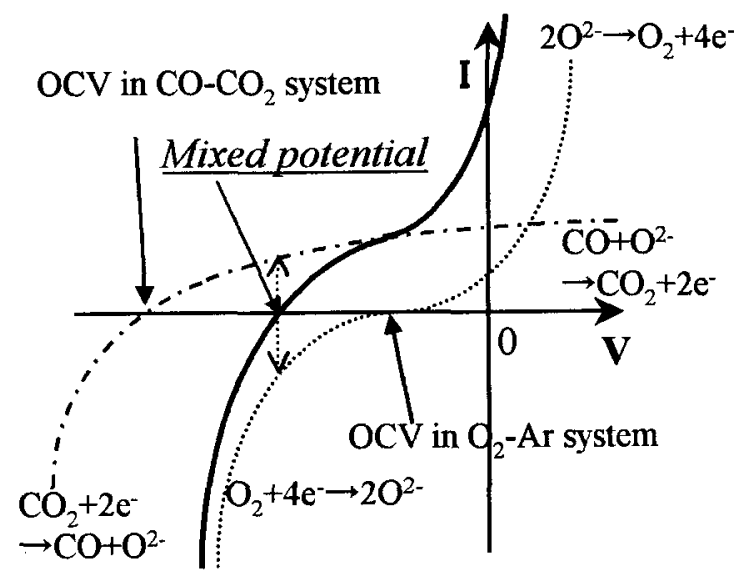

Fig.1 I-V characteristics of $\mathrm{Au} / \mathrm{YSZ}$ interface in $\mathrm{CO}-\mathrm{O}_{2}-\mathrm{Ar}$ mixtures.

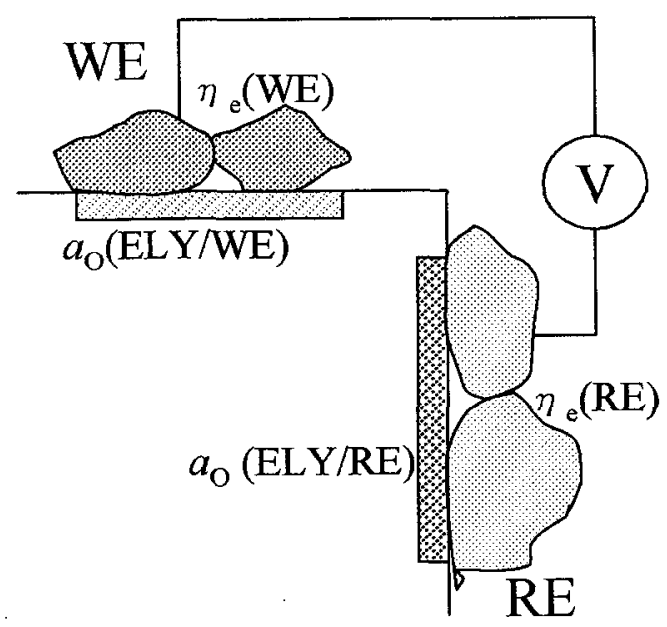

Fig.2 Physical meaning of electrode potential.
ル変化であり, 電解質でのIR 損に相当する。この項の値は電 解質抵抗により決まり，RE-WE間の電極電位と併せて，電極/ 電解質界面間での化学ポテンシャル差を決定することができ る.それゆえ，REの酸素分圧を制御し，REに気相と速やか に平衡に達する可逆電極を用いて $\mu_{0}(\mathrm{ELY}, \mathrm{RE})$ を規定すると， Nernst の式により電極電位 $E$ から ELY/WE界面の酸素活量 $a_{0}$ (ELY, WE) を決定することができる.

$$
\begin{aligned}
E-I R(E L Y) & =\mu_{0}(\mathrm{ELY}, \mathrm{WE})-\mu_{0}(\mathrm{ELY}, \mathrm{RE}) \\
= & \frac{R T}{2 F} \operatorname{In} \frac{a_{0}(\mathrm{ELY}, \mathrm{WE})}{a_{0}(\mathrm{ELY}, \mathrm{RE})}=\frac{R T}{2 F} \ln \frac{a_{0}(\mathrm{ELY}, \mathrm{WE})}{P_{\mathrm{O}_{2}}(\mathrm{RE})^{1 / 2}}
\end{aligned}
$$

通電時には，一般にはELY/WE界面での電子の平衡は成り 立たない。しかし, 固体電解質系では電子の移動度がイオン に比べて数桁大きいので，近似的に ELY/WE界面の電子は常 に平衡状態であるとみなす事ができる》。.よって，RE-WE間 に電圧 $E$ を印加することにより， $a_{0}(\mathrm{ELY}, \mathrm{WE})$ を規定するこ とができる。

\section{3 実 験}

\section{1 試料作製}

試料として，電極形状による違いが存在するかを明らかに するため,電極の寸法がわかるメッシュ電極を使用したもの, 及び，ペーストを滁布して作製した多孔質電極の 2 種類を用 いた.メッシュ電極付の試料は, 電解質として両面研磨した $8 \mathrm{~mol} \% \mathrm{Y}_{2} \mathrm{O}_{3}$ 添加 $\mathrm{ZrO}_{2}$ 結晶 $(100)(\phi 10 \times 3 \mathrm{~mm}$, アースジュエリー 製)ペレットと市販の透過型電子影微鏡試料保持用の金メッ シュ䈃 $(400$ メッシュ， $\phi 3 \mathrm{~mm}$ ，厚さ $15 \mu \mathrm{m})$ を使用した. 試料 の片面に作用極 (WE) として金メッシュ箔を $1050^{\circ} \mathrm{C} \times 1 \mathrm{~h}$ で焼 き付け，董面から顕微鏡観察で密着していることを確認した 後, Ptペースト(TR7905, 田中貴金属)を側面及び亭面に $900^{\circ} \mathrm{C}$ $\times 1 \mathrm{~h}$ で焼き付けて多孔質の電極を作り, 参照極 (RE), 対極 (CE) とした. 多孔質電極の試料としては, 市販の $8 \mathrm{~mol}^{2} \mathrm{Y}_{2} \mathrm{O}_{3}$ 添加 $\mathrm{ZrO}_{2}$ の粉末加高密度円盤状焼結体 $(\phi 13 \times 2 \mathrm{~mm})$ を作製 して電解質として用い，テレヒン油に分散させた金粉 (粒径 $0.5 \mu \mathrm{m}$ 徳力)を電解質の片面に厚さ約 $20 \mu \mathrm{m}$ に湬布し作用極と し，襄面及び側面にそれそれれ Ptペーストを塗布し，対極及び 参照極とした。電極の焼付けは $800^{\circ} \mathrm{C} \times 2 \mathrm{~h}$ で行った.

3.2 実験方法

測定装置の概略をFig.3に示す.Pyrex®シールにより作用極 雾囲気と, 対極, 参照極雾囲気とを分離し, 参照ガスとして 常時 $1 \% \mathrm{O}_{2}$-Ar $\mathrm{CE}$, REに，被検ガスとして混合比を制御した $\mathrm{O}_{z}-\mathrm{Ar}, \mathrm{CO}-\mathrm{CO}_{2}, \mathrm{CO}-\mathrm{O}_{2}-\mathrm{Ar}$ ガスをWEにそれぞれ一定流量で供 給し，雾囲気を制御した．また，混合ガスが非平衡のままの 状態でWEに供給されるようにするため,WEに至るガス経路 の高温部では集電用の金以外の金属が露出しないようにした. それそれれ電極の雲囲気を制御した状態で，開回路時の起電 力, および定常分極状態での電流と電極電位の関係の測定を ポテンショ・ガルバノスッタット(PS-2000, 東方技研) を使 用して行った。その際に誤差として含まれる電解質抵抗の影 
響を除去するため, 分極測定後に随時 FRA(Type 5080, NF 回 路ブロック)を併用してインピーダンス測定を行い，補正を

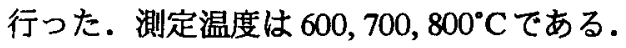

\section{4 結果およひ考䕓}

一般に電極反応での電流と電極電位の関係は Butler-Volmer の式で表される.

$$
I=I_{\mathrm{O}}\left[\exp \left(\frac{\alpha F\left(E-E_{\text {eq }}\right)}{R T}\right)-\exp \left(\frac{\beta F\left(E-E_{\text {eq }}\right)}{R T}\right)\right]
$$

ここで $E_{\mathrm{eq}}$ は平衡電位, $\alpha, \beta$ は定数であり $\alpha+\beta=\mathrm{n}(\mathrm{n}:$ 注目す る反応の律速過程における電子の移動数)という関係が成り立 つ. $I_{\mathrm{O}}$ は交換電流密度と呼ばれ，反応種の濃度に依存する項 で, $P\left(\mathrm{O}_{2}\right), P(\mathrm{CO}), P\left(\mathrm{CO}_{2}\right)$ などの関数になる.この式の電極電 位を式(5)で電極界面の酸素活量 $a_{0}$ の形に書き直すと

$$
I=k P(X)^{m} a_{\circ}^{p}-k^{\prime} P(Y)^{n} a_{\circ}^{q}
$$

と表せる．ここで， $\mathrm{P}(\mathrm{X}), \mathrm{P}(\mathrm{Y})$ は注目している電極反応に関 与する化学種のガス分圧である. 結果の考察にあたっては， まず分極測定における電極電位 $E$ を電極界面の酸素活量に换 算して, 電流電位曲線を電流密度と電極界面の酸素活量 $a_{0}$ と の関係で表現する．また，単一の反応が起こるガス種だけの 組み合わせ，すなわち $\mathrm{O}_{2}-\mathrm{Ar}$ 系, $\mathrm{CO}^{-} \mathrm{CO}_{2}$ 系について電流密度 を各ガス分圧と $a_{0}$ の関数で表現してそれぞれの系での速度式 の定式化を試みる.その結果から化学反応式を決定し反応機 構を求める.その結果により二共役系の $\mathrm{CO}_{2} \mathrm{O}_{2}$ - $\mathrm{Ar}$ 系について 議論を進める。

\section{$4.1 \mathrm{O}_{2}-\mathrm{Ar}$ 系での電極反応}

Fig.4に $\mathrm{O}_{2}$-Ar 雾囲気での Au/YSZ 電極の電流密度 $j$ と電極で の酸素活量 $a_{0}$ の関係を示す. 電極形状の違いによる影響を観

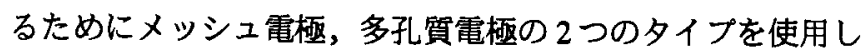
ているが, 2つの電極で有意な違いは観測されず，双方ともア ノード反応において雾囲気の酸素分圧には依存せず， $a_{0}$ にの

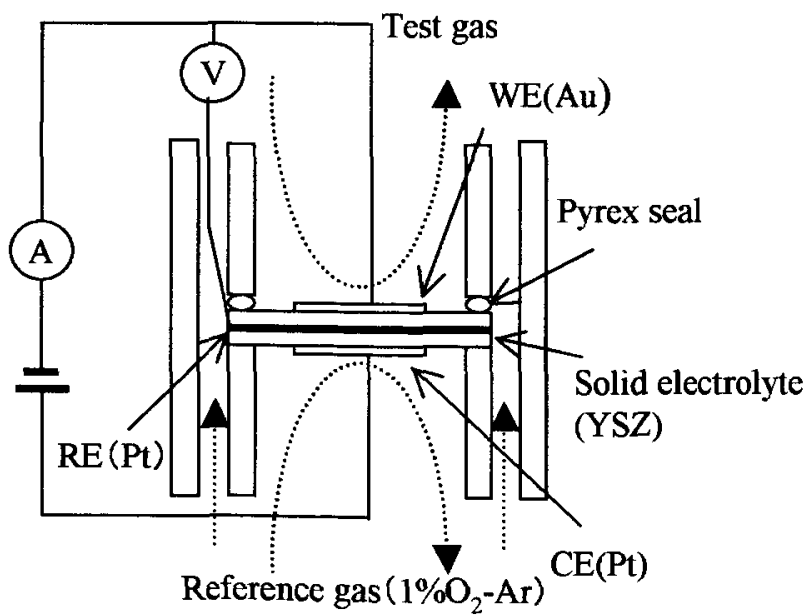

Fig.3 Schematic view of experimental setup.
み線形に依存している．よって大きくアノードに分極したと きの電流密度は以下のように表せる。

$$
j=k a_{0}
$$

一方，式(8) と反応次数が整合し，交換反応速度が一致する ようなカソード反応を考えると，

$$
j=k P\left(\mathrm{O}_{2}\right)^{1 / 2}
$$

のようになる.実測值ではカソード電流密度は $a_{0}^{-1 / 4}$ にも依存 しているように見える.しかし，カソード電流密度が $a_{0}{ }^{-1 / 4}$ に 依存していると考えると，カソード，アノード両反応の交换 電流密度が一致せず，矛盾が生じる．このことから，実測し たカソード反応は, 式(9)の反応と不純物ガスによる別の反応 が重畳したものと考えられる。しかし，不純物ガスの影響を 考虑するにはテー夕が不十分であるため,ここでは式(8), (9) で $\mathrm{O}_{2}-\mathrm{Ar}$ 系の電流密度が記述できるとして議論を進める。 よって電流密度は,

$$
j=k_{0}\left(a_{0}-P\left(\mathrm{O}_{2}\right)^{1 / 2}\right)
$$

と表される.この速度式から予想される律速反応は，電極上 での吸着酸素 $\mathrm{O}_{\mathrm{ad}}$ の移動，また㹥電極内部での酸素の抎散な ど, 電極部分での酸素原子(酸化物イオン)の移動過程である と考えられる。

\section{$4.2 \mathrm{CO}-\mathrm{CO}_{2}$ 系での電極反応}

Fig. 5 に $\mathrm{CO}-\mathrm{CO}_{2}$ 雾囲気での Au/YSZ 電極の酸素活量 $a_{0}$ と $P$ (CO)の関係を示す.3種のテータはそれそれ多孔質電極, メッ シュ電極，多孔質YSZ+メッシュ電極のものであり，電極の 種類により，電極での $a_{0}$ が大きく違うことがわかる。この理 由として形状により電極の活性が異なること，および，市販 の高純度 $\mathrm{CO}$ (>99.95\%), $\mathrm{CO}_{2}$ (>99.99\%)ガス中の不純物の影響 が考えられる. 不純物としては $\mathrm{O}_{2}(<20 \mathrm{ppm}), \mathrm{CH}_{4}(<10 \mathrm{ppm})$, $\mathrm{H}_{2}(<10 \mathrm{ppm})$ などが挙げられるが,これらの不純物が電極へ未

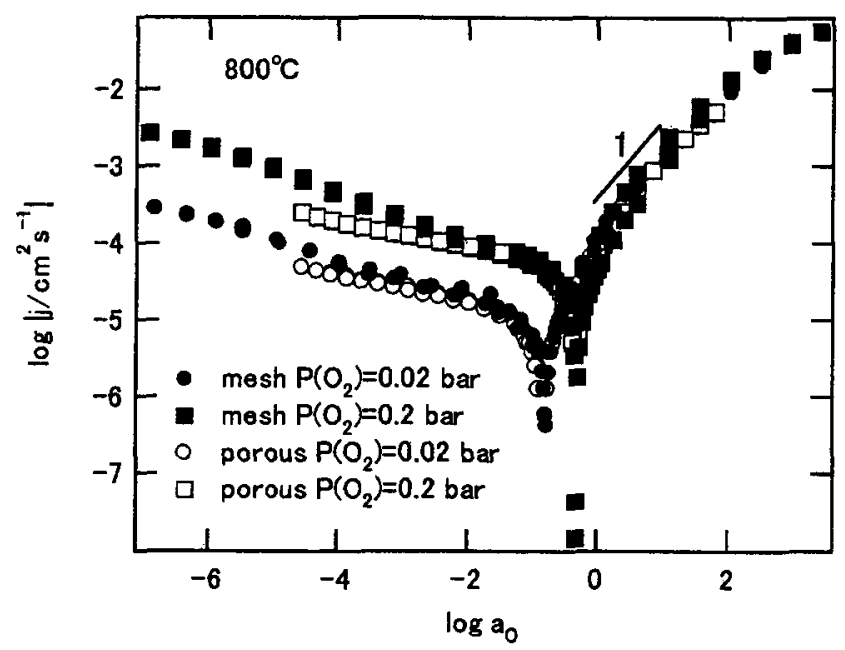

Fig.4 Steady-state polarization current densities as a function of oxygen potential on the working electrode in $\mathrm{O}_{2}-\mathrm{Ar}$ system at $800^{\circ} \mathrm{C}$. 
反応のまま到達し，電極上で反応することで混成電位が生じ ている可能性が高い. 確認のため不純物ガスが電極に到達す る前に平衡化するように，多孔質のYSZを電極上に配置して ガスの拡散距離を稼いで同様の測定した結果，Fig.5に示すよ うに開回路電位はほほ $\mathrm{CO}-\mathrm{CO}_{2}$ 雰囲気の平衡電位となった(図 中の実線はNernstの式により計算した平衡電位). また, 多孔 質YSZがないときには，不純物による混成電位の発生で開回 路電位が平衡電位から大きくずれていると考えられる。

しかし，Fig.6より反応速度式の決定に影響するI-V曲線の 形状は不純物の影翌によっても，それ程変化しないことがわ かる.よって以下では，これらの定常分極測定の結果から反 応機構を推察する. $\log a_{0}>-1$ の領域で電流密度 $j$ は $a_{0}$ に線形 に依存している.この領域でのjは $\mathrm{P}(\mathrm{CO})$ に依存せず, $\mathrm{O}_{2}-\mathrm{Ar}$ 系のアノード反応と同様の傾向を示していることから酸素発 生反応を表していると考えられる.また，開回路電位から酸 素発生反応が支配的になる領域の間では，電流密度は $a_{0}{ }^{1 / 2}$ と

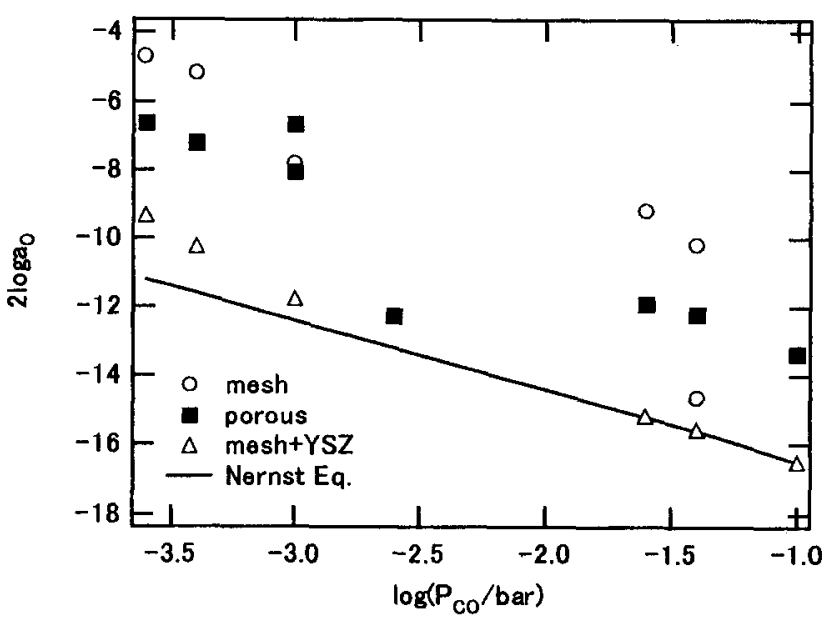

Fig.5 The dependence of oxygen potential at Au/YSZ interface on partial pressure of $\mathrm{CO}$ in $\mathrm{CO}-\mathrm{CO}_{2}$ system at $800^{\circ} \mathrm{C}$.

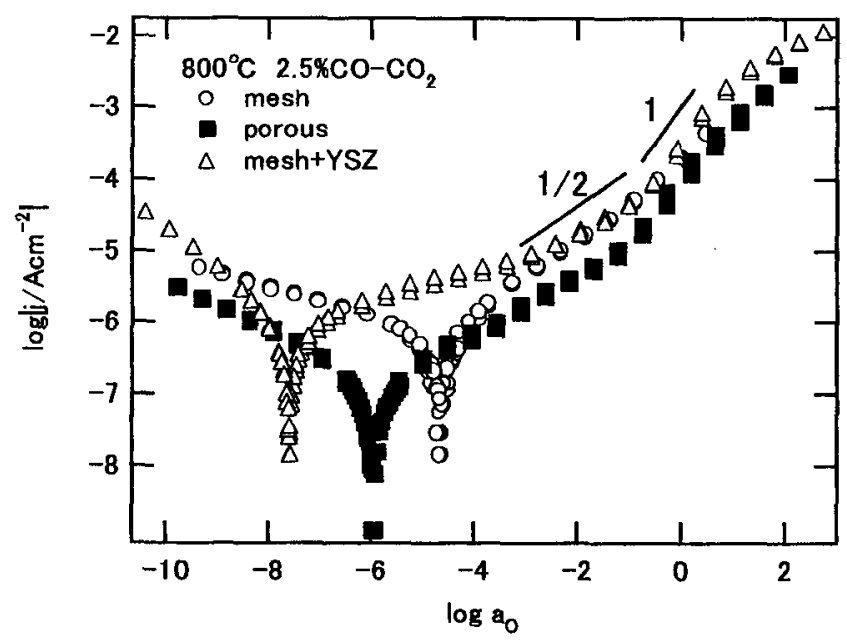

Fig.6 Steady-state polarization current densities as a function of oxygen potential on the working electrode in $\mathrm{CO}-\mathrm{CO}_{2}$ system at $800^{\circ} \mathrm{C}$.
$P(\mathrm{CO})^{1 / 2}$ に依存している.一方，力ソード反応は $P(\mathrm{CO})$ には 依存せず， $a_{0}{ }^{2 / 4}$ に比例している. $P\left(\mathrm{CO}_{2}\right)$ への依存は $P\left(\mathrm{CO}_{2}\right)$ を 大きく変化させていないので明確になっていないため,ア ノード反応と反応次数が整合するように決めた。此上り， $\mathrm{CO}-\mathrm{CO}_{2}$ 系での反応の傾向は $\mathrm{Pt} / \mathrm{YSZ}$ 系 ${ }^{8)}$ と同様となり, 速度 式は以下のように表される。

$$
j=k_{\mathrm{Co}}\left(P(\mathrm{CO})^{1 / 2} a_{\circ}{ }^{1 / 2}-P\left(\mathrm{CO}_{2}\right)^{1 / 2}\right)
$$

よって，律速過程の反応は三相界面を介して起こる

$$
\mathrm{CO}_{\mathrm{ad}}(\mathrm{Au})+\mathrm{O}_{\mathrm{ad}}(\mathrm{YSZ}) \rightarrow \mathrm{CO}_{2 \mathrm{ad}}(\mathrm{Au})
$$

と考えられる.

\section{$4.3 \mathrm{CO}^{-\mathrm{O}_{2}}-\mathrm{Ar}$ 系での電極反応}

2.2 節で述べたように， $\mathrm{CO}-\mathrm{O}_{\tau}-\mathrm{Ar}$ 系では $\mathrm{CO}$ は $\mathrm{O}_{2}$ に対して 微量であるので，主に $\mathrm{O}_{2}$ 系の反応により開回路電位は決ま る.それゆえ, $\mathrm{CO}-\mathrm{CO}_{2}$ 系のカソード反応はほとんど無視で き, $\mathrm{CO}-\mathrm{CO}_{2}$ 系のアノード反応と $\mathrm{O}_{2}-\mathrm{Ar}$ 系の反応が同時に進行 して混成電位を生じると考えられる。よって式(10),(11)より この系での電流密度は,

$$
j=k_{\mathrm{CO}} P(\mathrm{CO})^{1 / 2} a_{0}^{1 / 2}+k_{0}\left(a_{0}-P\left(\mathrm{O}_{2}\right)^{1 / 2}\right)
$$

と表される. 式(13)でこの系のI-V特性を表現できれば, 微 量のCOによる化学ポテンシャルのシフトが混成電位により 定量的に説明できるといえる。すなわち，パラメー夕である $k_{\mathrm{C}}, k_{\mathrm{o}}$ を $\mathrm{CO}-\mathrm{CO}_{2}$ 系， $\mathrm{O}_{2}-\mathrm{Ar}$ 系の測定結果よりそれそれ求め， それらと式(12)で $\mathrm{CO}-\mathrm{O}_{2}-\mathrm{Ar}$ 系の I-V 特性が解积できれば良 い.しかし, $\mathrm{CO}-\mathrm{CO}_{2}$ 系における測定では不純物の影響が大き く，正確に $k_{\mathrm{co}}$ が求められない，よって，以下では $k_{\infty}$ を不純 物が少ない $\mathrm{CO}-\mathrm{O}_{2}-\mathrm{Ar}$ 系の開回路電位の CO分圧依存性より求 め，それによって $\mathrm{CO}-\mathrm{CO}_{2}$ 系の分極テータが説明可能かとい うことで，混成電位モテルが適用できるかを論ずる。

式(13)より開回路時 $\left(j=0 \mathrm{Acm}^{-2}\right)$ には,

$$
P(\mathrm{CO})=\frac{k_{\circ}^{2}\left(a_{0}-P\left(\mathrm{O}_{2}\right)^{-1 / 2}\right)^{2}}{k_{\mathrm{O}}^{2} a_{0}}
$$

なる関係が成り立つ.まず, $\mathrm{O}_{2}-\mathrm{Ar}$ 系の I-V 特性を式 (10)で フィッティングして $k_{0}$ を求めた(Fig.7). Fig.8は開回路電位の $\mathrm{CO}$ 分圧依存性と, $k_{\mathrm{co}}$ をバラメータとして式 (14)でフィッ ティングした例を表している.その結果得られた $k_{\mathrm{co}}$ の温度依

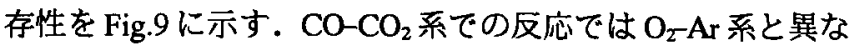
り多孔㙺電極の方がより高い反応性を持つように見える.し かし，テータにばらつきがあるため電極の形状に由来する違 いかどうかは今後さらに検討する必要があろう.

次に得られた $k_{\mathrm{Co}}$ により $\mathrm{CO}-\mathrm{CO}_{2}$ 系の電極反応が記述できる かを確認する.パラメータ $k_{\mathrm{co}}$ より計算したアノード電流密度 の酸素活量依存性を Fig.10に直線で示す. $\log a_{0}>-1$ の領域で は実測値は $\mathrm{O}_{2}-\mathrm{Ar}$ 系と同しく酸素発生反応が主となり電流密 度 $j$ は $a_{0}$ に線形に依存するため, 式(12)の反応が起こるとし た計算值とは傾向が異なる．しかし，それ以外のアノード反 


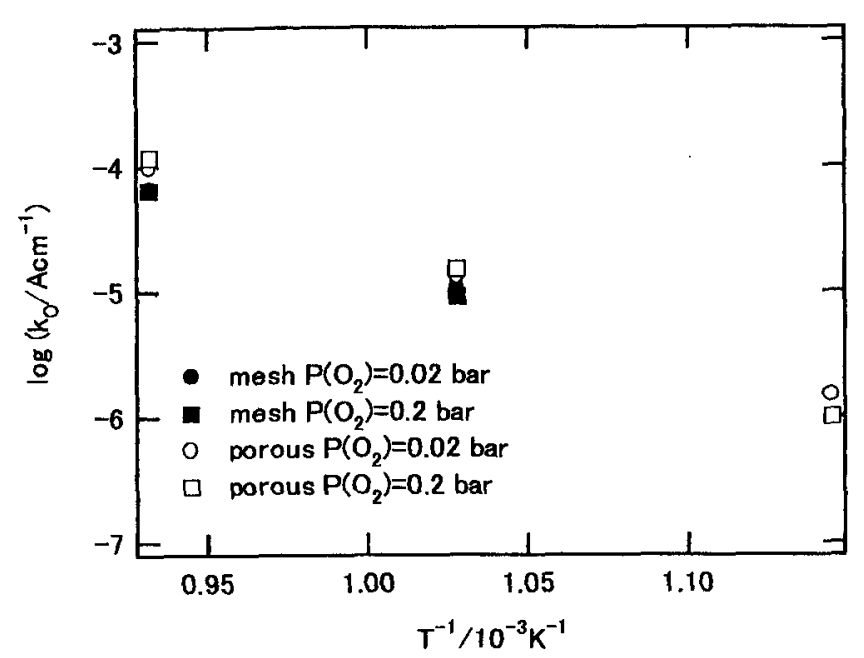

Fig.7 Temperature dependence of the reaction rate constant, $k_{\mathrm{o}}$, in $\mathrm{O}_{2}$-Ar system.

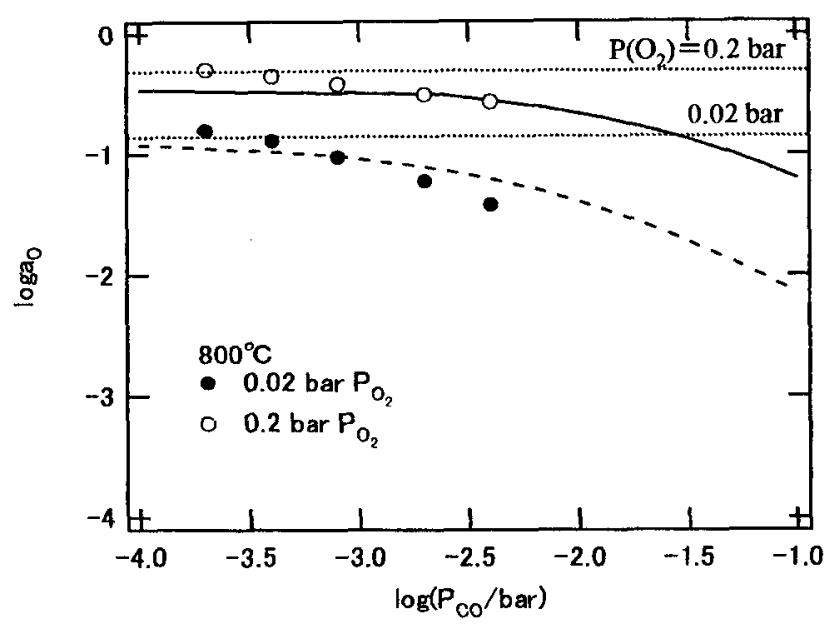

Fig.8 Typical dependence of oxygen activity at WE on carbon monoxide partial pressure. Dotted and solid lines are the fitting curves on the condition of $P\left(\mathrm{O}_{2}\right)=0.02$ and $0.2 \mathrm{bar}$, respectively, at $800^{\circ} \mathrm{C}$.

応域では電流密度 $j$ の計算值は実測值の約半分程度であるが， 傾向はほほ一致することが見て取れる.よって，不純物の影 響により多少混成電位にずれが見られるものの，微量のCO による化学ポテンシャルシフトが湦成電位機構により起こる と説明できる。

\section{5 結 言}

$\mathrm{Au} / \mathrm{YSZ}$ 界面での $\mathrm{O}_{2}-\mathrm{Ar}, \mathrm{CO}-\mathrm{CO}_{2}$ ，および $\mathrm{CO}_{2} \mathrm{O}_{2}-\mathrm{Ar}$ 雾囲気 下での定常分極測定の結果から電極反応過程を解析した結果, $\mathrm{O}_{2}$ 雰囲気中での微量の $\mathrm{CO}$ による化学ポテンシャル変化を混 成電位モデルを用いてほほ説明できることが分かった. 今後 の課題として，雾囲気中の微量不純物ガスによっても混成電 位が発生するため, 影響する不純物の同定と効果の定量化を 行う必要がある。

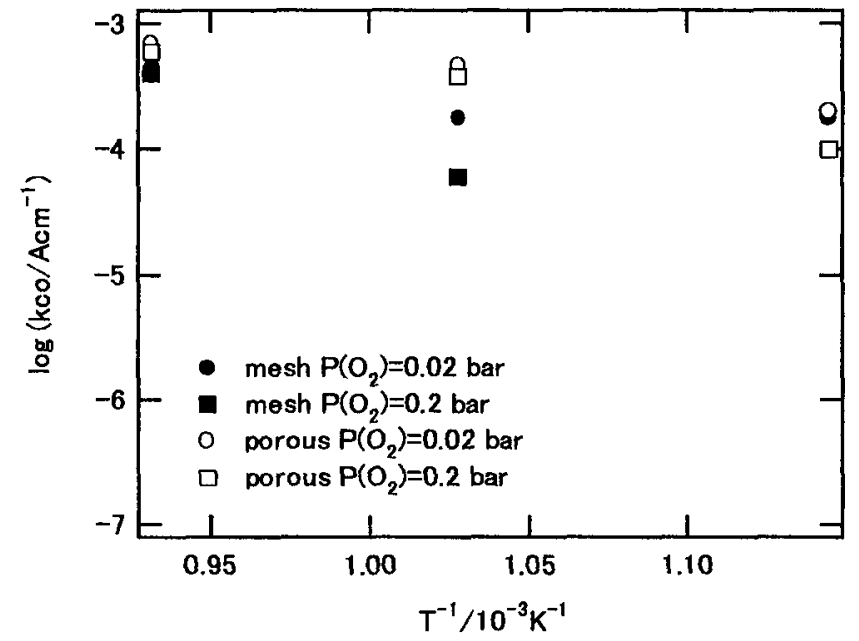

Fig.9 Temperature dependence of the reaction rate constant, $k_{\mathrm{CO}}$, in $\mathrm{CO}-\mathrm{CO}_{2}$ system.

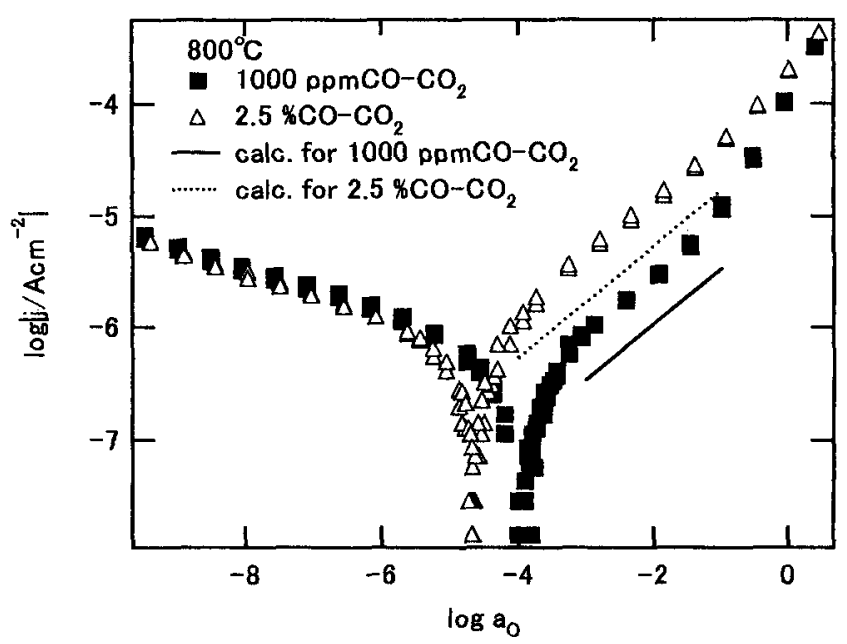

Fig.10 The comparison of $\mathrm{I}-\mathrm{V}$ curves in $\mathrm{CO}-\mathrm{CO}_{2}$ system with calculated values of anodic current densities at $800^{\circ} \mathrm{C}$. Calculated values from Eq. (11) are shown as lines.

\section{謝辞}

本研究は, 科学技術庁の平成 11 年度科学技術振興調整費に よる「協奏反応場の增幅制御を利用した新材料創製に関する 研究」の一環として行われたものである.

\section{文献}

1) 清山哲郎ほか : 化学センサー, 講談社, (1982)56.

2) H.Okamoto et al.: "Carbon monoxide gas sensor ..." Solid State Ionics, 1(1980)319-326.

3) R.Sorita and T.Kawano: "A highly selective CO sensor ..." Sens. Actuators B, 40(1997)29-32.

4) N.Miura et al.: "Highly selective CO sensor ..." Sens. Actuators B, 47(1998)84-91.

5) R.Mukundan et al.: "Ceria-electrolyte-based Mixed potential sensors ..." Electrochem. Solid State Letters, (1999)412-414. 
6) Z.Y.Can et al.: "Detection of carbon monoxide ..." Solid State Ionics, 79(1995)344-348.

7) 水崎純一郎: " 固体電解質を対象にした参照電極", 電気化
学, 62(1994)772-774.

8) J.Mizusaki et al.: "Kinetics of the electrode reaction ..." Solid State Ionics, 53-56(1992)126. 